прецедентных имен путем освещения закономерностей их стилистического выражения в произведениях современной англоязычной художественной литературы. Анализ иллюстративного материала базировался на обобщенной классификации прецедентных имен, охватывающей их разделение по критерию принадлежности к социокультурной группе определенного уровня (универсально-прецедентные, национально-прецедентные и социумно-прецедентные), а также по семантическому критерию (прецедентные антропонимы и топонимы; терминологические и полисемические прецеденты). Среди наиболее многочисленных эталонных тематических групп прецедентных имен зарегистрированы имена исторических личностей, героев классических произведений и фильмов, мифологемы, реализующиеся в тексте через ряд стилистических фигур, таких как метафора, гипербола и сравнения. К ведущим критериям, служащим основанием для различия прецедентных феноменов от других имен, относим апеллирование к признакам внешности людей или персонажей, черт характера или коммуникативных ситуаций, через которые проявляется знаковость героя или выдающейся личности. Прецедентные имена, будучи одной из вербальных форм отражения стереотипно-метафорического восприятия действительности определенной культурной общностью людей, демонстрируют тенденцию к расширению своего контекстуального значения и приумножению характеристик, благодаря своей способности формировать ментальные связи между первоисточником и новым контекстом. Выполненный анализ иллюстративного материала показал, что прецедентные имена относятся к действенным средствам привлечения внимания читателя к определенной идее произведения, а также интенсификации конкретных черт и особенностей персонажей художественной литературы XXI в. К перспективным направлениям относим изучение вопросов, связанных с суггестивным и эмоциональнопрагматическим потенциалами прецедентных имен, а также углублением знаний о синергетических процессах их порождения и актуализации в рамках различных лингвокультур.

Ключевые слова: прецедентное имя, классификация, стилистический прием, художественная литература, функциональное назначение.

Taranenko Larysa, Shestopal Yelyzaveta. Lingual Specificity of Precedent Names Used in Modern English Literature. The paper is focused on the study of specificities of precedent names' use in modern English by means of highlighting the patterns of their linguistic and stylistic expression in the works of present-day English fiction. Being studied in various discourses, precedent names are underrepresented in recent linguistic works. The illustrative material is carefully reviewed on the basis of the generalized classification of precedent names, covering their division according to the criterion of belonging to a certain sociocultural group (universal-precedent, national-precedent and socio-precedent names), as well as a semantic criterion (precedent anthroponyms, precedent toponyms; terminological and polysemantic precedents). Among the most numerous thematic groups of precedent names are the registered names of historical figures, heroes of classical literary works, films and mythologies, which are realized in the text through a number of stylistic devices, namely: metaphor, hyperbole and comparison. The key features taken as a basis of the precedent names formation are the following: appeal to the external features of people or characters, specific features of their characters, or the situations in which the character is portrayed. Results of the analysis clearly stated that the most numeric group of precedent names comprises universalprecedent type of names. Viewed as one of the verbal forms of reflection of stereotyped metaphorical perception of reality by a certain cultural community of people, precedent names hold the power to extend their areas of occurrence as they tend to reappear in new context groups. Precedent names expand their contextual meaning due to their ability to form mental connections between the source of their original and the new context. By performing the analysis, it was found out that precedent names belong to the effective means of drawing the reader's attention to a certain idea as well as serve to intensify the specific features and characteristics of the characters of the XXI century fiction. We see it perspective to study the issues related to the emotional-and-pragmatic potential of precedent names, as well as to deepen the knowledge about synergetic processes causing their generation and actualization within different lingual cultures.

Keywords: precedent name, cognitive basis, precedent names, universal precedent names, terminological names, polysemic names.

DOI: https://doi.org/10.32782/2410-0927-2020-13-26

УДК 376.043.2-056.2/.3(477)

Галина Тригуб, Оксана Хникіна

\title{
ОСНОВНІ ПРИНЦИПИ ТА ТРУДНОЩІ ЗАПРОВАДЖЕННЯ ІНКЛЮЗИВНОЇ ОСВІТИ У ВИЩИХ НАВЧАЛЬНИХ ЗАКЛАДАХ УКРАЇНИ
}

У статті досліджено основні проблеми запровадження інклюзивної освіти у вищих навчальних закладах України. У сучасних умовах доступність вищої освіти для молоді з обмеженими функціональними можливостями $\epsilon$ важливою соціальною й педагогічною проблемою. Інклюзивна вища освіта - один з етапів інтеграції студентів 3 особливими потребами в суспільство, що допомагає їм отримати бажану професію та самореалізуватися в професійній діяльності. У статті висвітлено особливості, завдання й принципи інклюзивної освіти. Окреслено іï базові функції, серед яких найважливішими є правова, функція соціалізації, виховна, освітня та економічна.

(C) Тригуб Г., Хникіна О., 2020 
Визначено ключові принципи інклюзивної освіти в Україні: науковість, системність, варіативність і корекційну спрямованість, індивідуалізацію, соціальну відповідальність сім'ї, міжвідомчу інтеграцію та соціальне партнерство. Розкрито психологічні аспекти процесу адаптації студентів до умов навчання у вищий школі. Розглянуто специфіку входження до навчального середовища студентів, які мають обмеження фізичного здоров'я. Проаналізовано труднощі адаптації студентів з особливими потребами під час інтегрованого навчання. Висвітлено основні форми та методи навчання молоді з обмеженими можливостями. Визначено можливі шляхи подолання проблем, пов'язаних 3 упровадженням інклюзивної освіти, а саме: вдосконалення законодавчої бази й принципів фінансування, створення сприятливого освітнього середовища, формування матеріально-технічної бази, урахування індивідуальних особливостей і потреб студентів, організація психологічної підтримки учасників навчального процесу, надання соціальної та медико-реабілітаційної допомоги, створення умов для соціалізації, самовизначення й самореалізації, підготовка адаптованих навчально-методичних матеріалів для студентів, кадрове забезпечення, подолання соціальних та професійних стереотипів, що передбачає надання допомоги випускникам з особливими потребами в працевлаштуванні й проведення широкої роз'яснювальної роботи серед роботодавців, у засобах масової інформації, у системі служб зайнятості.

Ключові слова: інклюзивна освіта, інтегроване навчання, студенти з особливими потребами, соціальнопсихологічна адаптація, студентське середовище.

Вступ. Розвиток сучасного суспільства України й процеси інтеграції в європейську спільноту гостро ставлять питання забезпечення соціального захисту громадян країни, особливо тих, хто потребує його найбільше. Зокрема, це діти з особливими освітніми потребами (далі ООП). Ідея інклюзії, що виникла внаслідок усвідомлення цінності багатоманітності та відмінностей між людьми, виключає будь-яку дискримінацію й відображає одну з головних ознак демократичного суспільства: усі діти є цінними членами суспільства і мають рівні права, зокрема щодо отримання освіти, незважаючи на особливості їхнього психофізичного розвитку [9, с. 10]. Інклюзія є соціальною концепцією, що передбачає гуманізацію суспільних відносин і дотримання прав осіб з обмеженими можливостями на якісну та доступну освіту.

Інклюзія в освіті $€$ частиною інклюзивного суспільства - це процес реального включення дітей з особливими потребами в активне суспільне життя в середовищі однолітків. Концепція інклюзивної освіти декларує, що всі діти $є$ цінними й активними членами суспільства.

Серед найважливіших проблем, які потрібно врахувати під час інтеграції людей 3 особливими потребами в суспільство, називаємо отримання освіти у вищих навчальних закладах (далі-BНЗ).

Аналіз досліджень цієї проблеми. Питання інклюзивної освіти та ії різноманітні аспекти досліджувалися багатьма педагогами та науковцями $[2 ; 3 ; 6 ; 8 ; 10 ; 11$ й ін.]. Проблеми специфіки навчання студентів з особливими потребами, а саме соціальної та психологічної адаптації й реабілітації студентів, різноманітних аспектів супроводу навчання студентів 3 інвалідністю в закладах вищої освіти стали предметом багатьох наукових досліджень [1;2; 3; 5; 7; $9 ; 13$ та ін.].

Вивчення специфіки інклюзивної освіти в Україні, окреслення основних проблем іiї впровадження у вищій школі та шляхів їх подолання є важливою

потребою для розвитку теорії й практики вітчизняної інклюзії, що зумовлює актуальніть цієї проблеми та потребує подальшої ії розробки. Окрім того, актуальність проблеми інклюзивної освіти пов'язана з неухильним зростанням чисельності дітей і студентів, які потребують соціально-психологічної адаптації та корекційного навчання.

Мета й завдання статті. Мета статті - висвітлення основних завдань, принципів, функцій інклюзивної освіти в Україні, а також окреслення головних проблем запровадження інклюзивної освіти у вищих навчальних закладах та шляхів їх подолання, що передбачає виконання конкретних завдань:

- визначити особливості розвитку інклюзивної освіти в Україні;

- проаналізувати основні завдання й функції інклюзивної освіти;

- висвітлити ключові принципи інклюзивної освіти у вищий школі;

- розглянути основні проблеми запровадження інклюзивної освіти в

- закладах вищої освіти України;

- проаналізувати труднощі адаптації студентів з особливими потребами

- під час інтегрованого навчання;

- висвітлити основні форми й методи навчання студентів з обмеженими 
- можливостями;

- окреслити шляхи розв'язання проблем, пов'язаних із психологічною та соціальною адаптацією студентів з особливими потребами.

Методи та методики дослідження. Для виконання поставлених завдань застосовано теоретичну методику дослідження, що включає аналіз наукової літератури, законодавчої бази у сфері інклюзивної освіти в Україні й статистичний метод.

Результати та дискусії. Інклюзивна освіта - явище недавнє, і процес його розвитку в нашій країні ще не закінчений, а перебуває на початкових етапах формування. Інклюзія в освіті спрямована на забезпечення якісної освіти для всіх. П̈ї основна ідея - від уключення в навчальних закладах до включення в суспільство. Спільне навчання має на меті не лише запобігти ізоляції дитини з особливими потребами від інших, але й забезпечити ії залучення до тих самих соціальних груп і мати таке саме щоденне життя, коли б вона не мала жодних особливих потреб [9, с. 23].

Мета інклюзивної освіти полягає в ліквідації соціальної ізольованості будь-яких категорій дітей та студентів. Навчальні заклади мають враховувати різноманітні потреби своїх учнів шляхом узгодження різних видів і темпів навчання й залучити комплекс різноманітних форм $\mathrm{i}$ методів для індивідуалізації навчального процесу.

Концепція інклюзивної освіти отримала розвиток із концепції інтеграції, що застосовується під час переходу до нових підходів освіти людей з ООП. Інтегрована форма навчання у ВНЗ передбачає спільне навчання студентів 3 інвалідністю разом 3 іншими. Інтеграція осіб з ООП відбувається шляхом перенесення елементів спеціальної освіти в систему загальної освіти. На сьогодні в Україні термінологія «особи з особливими освітніми потребами» досить вживана, але поширюється лише на людей із порушеннями психофізичного розвитку, $\mathrm{i}$ саме вони ідентифікуються як особи з особливими освітніми потребами та ті, що потребують інклюзивної освіти.

Особою з особливими освітніми потребами вважають людину, яка потребує додаткової постійної чи тимчасової підтримки в освітньому процесі з метою забезпечення ії права на освіту, сприяння розвитку іï особистості, поліпшення стану іiі здоров'я та якості життя, підвищення рівня участі в житті громади.

За останніми статистичними даними Міністерства соціальної політики України, загальна кількість осіб з інвалідністю становить $6 \%$ жителів України. За статистикою, з 2,5 млн студентів вітчизняних навчальних закладів I - IV рівнів акредитації 8 тис. становлять люди з особливими потребами. Небагато осіб з обмеженими можливостями, які здобули повну середню освіту, вступають до закладів вищої освіти. Тому гостро постає питання щодо створення умов для здобуття належного рівня освіти цією категорією населення.

Інклюзивна освіта передбачає створення освітнього середовища, яке б відповідало потребам і можливостям кожної дитини, незалежно від іiї особливих потреб. Тому стратегія інклюзивної освіти грунтується на наданні якісних освітніх послуг та адаптації освітнього середовища до потреб учнів. Отже, потрібно створити необхідні умови для повноцінного навчання людей з особливими навчальними потребами в навчальних закладах, уключаючи підготовку педагогічних працівників, надання індивідуальної підтримки в ході здобуття освіти 3 урахуванням потреб дитини, нозології захворювання, отриманні й обробці інформації для засвоєння навчальної програми, забезпечити їм державну підтримку.

Перед вітчизняними вищими навчальними закладами постала низка завдань, які стосуються забезпечення відкритості та доступності освіти для людей будь-якого віку, стану здоров'я й матеріального становища, усунення будь-яких проявів дискримінації, створення рівних можливостей для отримання якісної освіти, запровадження інклюзивної освіти на всіх рівнях.

Інклюзивна освіта виконує конкретні функції:

1) правову, яка характеризується:

- забезпеченням прав осіб з ООП на здобуття освіти в умовах звичайних закладів освіти за місцем проживання дитини;

- попередженням і боротьбою з виключенням в освіті; 
- виявленням й усуненням чинників, що перешкоджають реалізації права дитини з ООП на освіту на умовах рівності та доступності;

2) функцію соціалізації, що проявляється у:

- засвоєнні особами з ООП широкого кола цінностей, соціальних ролей та очікувань, на основі яких складається повсякденне життя людей, а також тих, що пропагуються закладом освіти;

- формуванні людської особистості на основі засвоєння людьми з ООП знань, навичок, цінностей культурної спадщини, накопичених соціумом;

- уключенням осіб з ООП у соціокультурний простір школи, заклади вищої освіти, громад, держави;

3) виховну функцію, що передбачає:

- формування позитивного й толерантного ставлення суспільства до осіб з ОПП як до рівних, створення соціокультурного середовища;

- формування в людей з ООП почуття поваги та власної гідності, усвідомлення того, що вони є повноцінними членами суспільства;

4) освітня функція, яка полягає в засвоєнні дітьми з ОПП системи знань, умінь і навичок, необхідних для розвитку потенціалу та подальшої успішної інтеграції в суспільство;

5) економічну функцію, що реалізується у:

- підготовці осіб з ОПП до трудової діяльності, розвиток і використання їхнього потенціалу на ринку праці [9, с.13].

Ключовими принципами розвитку інклюзивної освіти в Україні є:

- науковість (розробка теоретико-методологічних основ інклюзивного навчання, програмно-методичного інструментарію, аналіз і моніторинг результатів упровадження інклюзивного навчання, оцінка ефективності технологій, що використовуються для досягнення позитивного результату, проведення незалежної експертизи);

- системність (забезпечення рівного доступу до якісної освіти дітей 3 особливими освітніми потребами, наступності між рівнями освіти: рання допомога - дошкільна освіта загальна середня освіта);

- варіативність, корекційна спрямованість (організація особистісно орієнтованого навчального процесу в комплексі 3 корекційно-розвивальною роботою для задоволення соціально-освітніх потреб, створення умов для соціально-трудової реабілітації, інтеграції в суспільство дітей із порушеннями психофізичного розвитку, у тому числі осіб з особливими потребами);

- індивідуалізація (здійснення особистісно орієнтованого індивідуального, диференційованого підходу);

- соціальна відповідальність сім’ї (виховання, навчання й розвиток дитини; створення належних умов для розвитку іï природних здібностей, участь у навчально-реабілітаційному процесі);

- міжвідомча інтеграція та соціальне партнерство (координація дій різних відомств, соціальних інституцій, служб із метою оптимізації процесу освітньої інтеграції дітей 3 особливими освітніми потребами) .

Під час вступу до вищих навчальних закладів у студентів з ООП виникають серйозні труднощі, які пов'язані з процесом соціально-психологічної адаптації та соціалізації. Умовою й результатом адаптації особистості є сформованість соціально та професійно значущих засобів спілкування, поведінки та діяльності, які суспільство визнає та підтримує. Вступ до ВНЗ є переломною подією в житті молодих людей. Особливості переходу із середньої до вищої школи пов'язані не лише з перебудовою провідного типу діяльності, але й із входженням особистості в новий колектив. Найбільші труднощі полягають у зміні соціальної позиції під час переходу зі шкільного соціуму, зміні способів навчальної діяльності, зміни звичних для школяра зв'язків, відносин і стереотипів поведінки [7, с. 192].

Серед нових соціально-психологічних проблем, що гальмують процес адаптації, виокремлюють незадовільний стан здоров'я; обмеженість місць для дозвілля; труднощі 
поєднувати навчання з роботою; невміння налагодити контакт з викладачами, конфлікти з ними; небажання брати участь у громадській роботі; невпорядкованість університетського побуту $[4$, c. 28$]$.

Важливими принципами впровадження інклюзивної освіти у вищий школі є:

1. Удосконалення нормативно-правової бази забезпечення освіти молоді з особливими потребами в Україні. Оскільки більшість законів із питань освіти щодо надання освітніх можливостей людям з особливими потребами не є реалізованими.

2. Наближення освіти до місця проживання студента 3 інвалідністю. Цей принцип може бути забезпечений через створення розгалуженої мережі філій вищого навчального закладу в різних регіонах країни, шляхом розбудови дистанційного навчання через інтернет.

3. Покращення матеріально-технічної бази закладів вищої освіти, що передбачає, поперше, певні заходи щодо забезпечення архітектурної безбар'єрності освітнього середовища, тобто наявність пандусів, спеціальних меблів, ліфтів, обладнання кімнат санітарно-гігієнічного призначення, усунення порогів та ін. Також, студенти мають бути забезпечені технічними засобами, які допоможуть компенсувати їхні вади.

4. Доуніверситетська адаптація студентів до інтегрованого освітнього середовища. Для таких студентів мають бути розроблені програми адаптації до вищої школи. Необхідною умовою адаптації $є$ ознайомлення з особливостями організації навчально-виховного процесу в закладах вищої освіти, зокрема формами проведення занять, індивідуальної й самостійної роботи, із формами контролю та принципами оцінювання знань студентів тощо.

Важливим моментом адаптації є попереднє включення абітурієнтів в інтегрований колектив і навчальний процес: навчання на курсах доуніверситетської підготовки, запрошення на спільні університетські заходи.

5. Гнучкий графік організації навчального процесу й викладання навчальних дисциплін.

Очевидно, що успішність студентів з інвалідністю залежить не лише від їхніх здібностей і здатності пристосуватися до інтегрованого освітнього середовища, але й від пристосованості навчального закладу до потреб студента з інвалідністю, підготовки педагогічного колективу до викладання в інтегрованому середовищіі, від морально-психологічного клімату в університеті загалом та в студентській групі зокрема [4].

Якщо розглядати мету освіти як пізнання, розвиток особистості, виховання окремих якостей, то стає очевидним, шо цілі вищих навчальних закладів для здорових студентів i студентів $з$ особливими потребами є однаковими. Досягнення цієї мети можливе шляхом застосування різних форм, методів і засобів навчання.

Для забезпечення інклюзивної освіти університети пропонуть сучасні форми навчання: денну, заочну, дистанційну, - залежно від рівня мобільності студента.

В освітньому процесі рекомендовано використовувати соціально-активні та рефлексивні методи навчання, технології соціокультурної реабілітації задля надання допомоги у встановленні повноцінних міжособистісних відносин 3 іншими студентами, створення комфортного психологічного клімату в студентській групі.

Використання активних методів навчання 3 метою активізації й мотивації навчання $\epsilon$ важливими не лише для здорових студентів, а також для студентів, які мають певні фізичні вади. Активізація їхньої уваги потрібна на кожному занятті: під час лекції, семінарського, практичного, лабораторного занять, та атестації. Лекція повинна проводитись у формі діалогу зі слухачами, шо сприяє активізації знань студентів, формуються навички аналітичного мислення, пошукової діяльності [2].

Практичні заняття також доцільно проводити із застосуванням активних методів організації навчання. До таких належать навчальні ігри: ділові, рольові, операційні, ситуативні й аналітичні. Зазначені форми проведення заняття $\epsilon$ дуже продуктивними й сприяють безболісному переходу студента від теоретичного навчання до реальних умов у виробничому середовищі.

Це особливо важливо для осіб з обмеженими функціональними можливостями, оскільки така ділова гра створює ланцюжок виробничих ситуацій, вирішення яких викликає в них 
почуття впевненості у власних силах, сприяє розвитку пізнавального інтересу, творчих здібностей студентів, покликана творити нові способи виконання управлінських завдань [2].

Окрім активізації навчання й використання його активних методів, упровадження дистанційної форми навчання $€$ важливим компонентом навчального процесу студентів 3 особливими потребами. Це відкриває нові перспективи для людей з обмеженими можливостями. Дистанційне навчання повинно бути цілісним, синтетичним, інтегрованим, гнучким, із широким застосуванням нових інформаційних технологій.

Необхідним для продуктивного навчального процесу студентів із фізичними вадами $\epsilon$ забезпечення друкованими та електронними освітніми ресурсами у формах, адаптованих до обмежень їхнього здоров'я, оскільки така категорія студентів має свої специфічні особливості сприйняття й переробки матеріалу. Студенти 3 тяжкими ураженнями мають бути своєчасно забезпечені, передусім, опорними конспектами лекцій, списками літератури, планами наступних занять, самостійними завданнями.

Важливими компонентами навчального процесу є проведення неформальних консультацій та організація додаткових курсів у разі потреби.

За необхідності для студентів з особливим потребами розробляються індивідуальні навчальні плани й графіки навчання. Під час складання індивідуального графіка навчання потрібно передбачити різні варіанти проведення занять: в освітній організації (в академічній групі та індивідуально), на дому з використанням дистанційних освітніх технологій.

6. Моніторинг успішності й проведення поточної та підсумкової атестації з урахуванням особливостей нозологій осіб з обмеженими можливостями здоров'я.

Для здійснення процедур поточного контролю успішності та проміжної атестації студентів освітня організація повинна створити фонди оцінних засобів, адаптованих для осіб 3 обмеженими можливостями здоров'я, які дають змогу оцінити досягнення ними запланованих в освітній програмі результатів навчання та рівень сформованості всіх компетенцій. Форма проведення поточної й підсумкової атестації для таких студентів установлюється з урахуванням індивідуальних психофізичних особливостей (усно, письмово на папері, письмово на комп'ютері, у формі тестування та ін). За необхідності студентам надається додатковий час для підготовки відповіді під час заліку або іспиту.

Контроль знань потрібно здійснювати постійно впродовж усього періоду навчання. Для роботи зі студентами 3 особливими потребами результативним $\epsilon$ тестовий контроль знань, що передбачає постановку системи запитань, відповідаючи на які, студенти виявляють певні рівні навчальних знань і вмінь психологічного розвитку, соціального досвіду.

7. Забезпечення психолого-педагогічного супроводу впродовж навчання. На етапі вступу це передбачає ознайомлення з попереднім досвідом навчання абітурієнтів, їхніми результатами, психологічне профорієнтаційне консультування, надання допомоги для оптимального визначення спеціальності. Крім того, на цьому етапі дуже важливо своєчасно виявити труднощі, що можуть виникнути в студентів під час навчання, і визначити їхні потреби в супроводі. Упродовж навчання педагогічний супровід забезпечується професорсько-викладацьким складом. Надзвичайно ефективною формою є тьюторська допомога, що передбачає підтримку осіб 3 інвалідністю іншими студентами-тьюторами: записувачами, супроводжувачами, консультантами.

Обов'язково має бути організована психологічна служба, до якої в разі виникнення проблем зможуть звертатися всі учасники навчального процесу: студенти з інвалідністю, інші студенти й викладачі.

8. Забезпечення умов для всебічного розвитку особистості. Професійний розвиток забезпечується як у межах навчального процесу, так і в системі позааудиторної роботи. Необхідною запорукою розвитку особистості $\epsilon$ залучення студентів до активного громадського життя університету, а саме до організації та участі в конкурсах творчості, спортивних змаганнях, студентському науковому товаристві, волонтерській роботі, патріотичних заходах, спільних подорожах, у всіх формах соціального життя [5, с. 16]. 
Необхідне завдання - це забезпечення сприятливого психологічного мікроклімату в інклюзивному середовищі, толерантних відносин між усіма учасниками навчально-виховного процесу, що поступово приведе до реальних позитивних змін у ставленні суспільства до людей $з$ особливими потребами як до рівних. Одним із ключових елементів цього процесу є створення умов для соціокультурної, духовної, творчої, фізичної та фізкультурно-спортивної реабілітації осіб з інвалідністю, розкриття їхніх здібностей, можливостей і талантів. Ураховуючи низький рівень соціалізованості молоді з особливими потребами, доцільно залучати їхні родини до участі в навчально-виховному та соціально-реабілітаційному процесах, використовувати накопичений ними в середній школі досвід щодо необхідних технологій навчання [5, с. 18].

Важливе завдання - надання допомоги випускникам 3 особливими потребами в працевлаштуванні та проведення широкої роз'яснювальної роботи серед роботодавців, у засобах масової інформації, у системі служб зайнятості.

Отже, дотримання зазначених принципів можуть допомогти розв'язати нагальні проблеми впровадження інклюзивної освіти у вищий школі та подолання труднощів, пов'язаних із психологічною й соціальною адаптацією студентів з обмеженими можливостями.

Висновки. Аналіз особливостей упровадження інклюзивної освіти у вищих навчальних закладах України дає підставу зробити такі узагальнення. Запровадження інклюзивного навчання в Україні на сьогодні $є$ багатоаспектною проблемою, що вимагає комплексного підходу до іï розв'язання, а саме: інтегрованого й одночасного розвитку спеціалізованої матеріально-технічної бази та навчально-методичної складової частини; інклюзивної компетентності викладачів і студентів; медико-реабілітаційної, соціально-психологічної, педагогічної та соціально-правової сфер.

Створення сприятливого інклюзивного освітнього середовища в системі вищої освіти $\epsilon$ можливим за співпраці закладів вищої освіти, батьків, громадських організацій і загалом держави. Об'єднання зусиль цих інститутів сприятимуть розв'язанню нагальних проблем запровадження інклюзивної освіти у вищий школі.

Перспективи подальшого дослідження вбачаємо в комплексному вивченні та аналізі форм і методів інклюзивної освіти, що сприяють соціально-психологічній адаптації студентів 3 обмеженими можливостями в умовах інтегрованого навчання.

\section{References}

1. Avksentieva, Tamila. 2016. "Shliakhy zaprovadzhennia inkliuzyvnoyi osvity u VNZ Ukrayiny". Naukovi zapysky Vinnytskkoho derzhavnoho pedahohichnoho universytetu imeni Mykhayla Kotsiubynskoho. Seriia: Pedahohika i psykholohiia. Vyp. 48: 135-138.

2. Barno, Tetiana. 2009. "Formuvannia professiinoi osvity studentiv $\mathrm{z}$ osoblyvymy potrebamy cherez zastosuvannia riznykh form ta metodiv navchannia". Aktualni problemy navchannia ta vykhovannia liudei $z$ osoblyvymy potrebamy: zbirnyk naukovyh prats. Kyiv: Universytet „Ukrayina”. № 6(8): 40-44.

3. Bondar, Tamara. 2014. "Stvorennia inkliuzyvnoho osvitnioho seredovyshcha v systemi vyshchoyi osvity Ukrayiny”. Science and Education a New Dimension. Pedagogy and Psychology. T. II, № 27: 20-24.

4. Chaykovskyi, Mykhailo. 2010. "Dosvid vprovadzhennia inkliuzyvnoho navchannya v universyteti «Ukrayina»". Zbirnyk naukovykh prats Khmelnytskoho instytutu sotsialnykh tekhnolohiy Universytetu «Ukrayina». № 2: 8-11.

5. Ivaniuk, I. 2009. "Adaptatsiia studentiv z obmezhennymy mozhlyvostiamy v umovah intehrovanoho navchania". Aktualni problemy navchannia ta vykhovannia liudei z osoblyvymy potrebamy: zbirnyk naukovyh prats. Kyiv: Universytet «Ukrayina». № 6(8): 24-32.

6. Kolchenko, Kateryna. 2013. "Kontseptualni pidkhody do vprovadzhennyia inkliuzyvnoyi osvity u vyshchykh navchalnykh zakladakh". Aktualni problemy navchannia ta vykhovannia liudey z osoblyvymy potrebamy. Kyiv: Universytet «Ukrayina». № 10(12): 12-22.

7. Kolupaieva, Alla. 2007. "Kontseptualni aspekty inkliuzivnoyi osvity". Inkliuzyvna shkola: osoblyvosti organizatsiyi ta upravlinnia: navchalno-metodichnii posibnyk. Kyiv.

8. Kondratova, Natalia.1999. "Problemy adaptatsii studentiv vyshchykh navchalnykh zakladiv: zmist, formy, psykhologichna spetsifika". Psykholohiia: zbirnyk naukovykh prats. Kyiv: NPU 189-196.

9. Lalak, Nataliia. "Pidhotovka maybutnikh pedahohiv do roboty $\mathrm{v}$ zakladakh osvity z inklyuzyvnoyu formoyu navchannya”. URL: http://prima.Inu.edu.ua/Pedagogika/periodic/pedos3t/tom1/23_lalak.pdf

10. Lesher, Olha. "Inkliuzivnoe obuchenie studentov universyteta: kompleks nauchnykh podkhodov". URL: https://www.science-education.ru/pdf/2015/1/1190.pdf

11. Poroshenko, Maryna. 2019. Inkliusyvna osvita: navchalnyi posibnyk. Kyiv: Ahenstvo "Ukrayina". 
12. Semeniuk, Antonina. 2019. "Uprovadzhennia osvitnioyi kontseptsii navchannia ditei z osoblyvymy potrebamy": Inivatsiina pedahohika. Odessa. № 11(3): 12-22.

13. Talanchuk, Petro. 2003. Suprovid navchannia studentiv z osoblyvymy potrebamy $v$ integrovanomu osvitniomu seredovishchi [Educational support of the disabled students in the integrated setting]. Kyiv.

Тригуб Галина, Хныкина Оксана. Основные принципы и трудности внедрения инклюзивного образования в высших учебных заведениях Украины. В статье иследуются основные проблемы внедрения инклюзивного образования в высших учебных заведениях Украины. В современных условиях доступность высшего образования для молодежи с ограниченными функциональными возможностями является важной социальной и педагогической проблемой. Инклюзивное высшее образование является одним из этапов интеграции студентов с особыми потребностями в общество и помогает им получить желаемую профессию и самореализоваться в профессиональной деятельности. В статье освещаются особенности, задачи и принципы инклюзивного образования. Определяются базовые функции инклюзивного образования, среди которых важнейшими являются правовая, функция социализации, воспитательная, образовательная и экономическая. Рассматриваются ключевые принципы инклюзивного образования в Украине: научность, системность, вариативность и коррекционная направленность, индивидуализация, социальная ответственность семьи, межведомственная интеграция и социальное партнерство. Раскрываются психологические аспекты процесса адаптации студентов к условиям обучения в высших учебных заведениях. Характеризуется специфика вхождения студентов с инвалидностью в студенческую среду. Обращается внимание на основные формы и методы обучения студентов с ограниченными возможностями. Анализируются трудности адаптации студентов с особыми потребностями во время интегрированного обучения. Определяются возможные пути преодоления проблем, связанных с внедрением инклюзивного образования в вузе, а именно: совершенствование законодательной базы, принципов финансирования, создания благоприятной образовательной среды, формирования материально-технической базы, учета индивидуальных особенностей и потребностей студентов, организации психологической поддержки участников учебного процесса; оказание социальной и медикореабилитационной помощи; создание условий для социализации, самоопределения и самореализации; подготовка адаптированных учебно-методических материалов для студентов; кадровое обеспечение; преодоление социальных и профессиональных стереотипов, что предусматривает предоставление помощи выпускникам с ограниченными возможностями в трудоустройстве и проведение широкой разъяснительной работы среди работодателей, в средствах массовой информации, в системе служб занятости.

Ключевые слова: инклюзивное образование, интегрированное обучение, студенты с особыми потребностями, социально-психологическая адаптация, студенческая среда.

Tryhub Halyna, Khnykina Oksana. The Main Principles and Problems of Implementing Inclusive Education in Higher Educational Institutions of Ukraine. The article is devoted to the study of the main problems of implementing inclusive education in higher educational institutions of Ukraine. The inclusive approach in education involves the creation of conditions to meet the specific needs of each individual in the society.

The article highlights the features, objectives and principles of inclusive education. The basic functions of inclusive education are analyzed. The most important functions are the legal function, function of socialization, educational and economic functions. The key principles of inclusive education in Ukraine have been outlined. The basic principles are the scientific, the systematic, the principle of variability and correctional orientation, the principle of individualization, social responsibility of the family and social partnership. The psychological aspects of student involvement and participation in learning environment have been revealed. The main features and difficulties of adaptation of students with disabilities during integrated learning have been also analyzed. Considerable attention is paid to the main forms annd methods of teaching students with disabilities.

Effective implementation of inclusive education in Ukraine is possible with the combination of certain factors: sufficient funding, improvement of regulatory and legal base, developing teaching methods of inclusive education, training of qualified professionals to work in inclusive educational environment and developing special educational programs. Creating a well-designed and student-friendly environment enhances the learning experience for all students, including those with disabilities. Accessibility is also a key aspect to aid students with special needs to participate in educational activities alongside with their peers.

Particularly important today is positive public opinion on tolerance towards people with disabilities, the implementation of advocacy among parents about the nature and content of inclusive education. Inclusive education helps students with special needs adapt to typical life situations, get rid of feelings of isolation and alienation, overcome social barriers and integrate into the society. It improves student communication and teamwork, creates a sense of responsibility for students who need assistance and acceptance.

Key words: inclusive education, integrated learning, socio-psychological adaptation, students with special needs, educational environment. 